\title{
Mobile communication technologies and ontological security
}

\author{
Tecnologías móviles de comunicación y seguridad ontológica
}

\author{
Bernardo Amigo / bamigo@u.uchile.cl \\ http://orcid.org/0000-0002-5427-3819 \\ Francisco Osorio / fosorio@u.uchile.cl \\ http://orcid.org/0000-0002-5515-2699 \\ María Cecilia Bravo / mcecilia@u.uchile.cl \\ http://orcid.org/0000-0003-1635-7920 \\ Universidad de Chile, Chile
}

\begin{abstract}
This paper analyzes the relationship between everyday life and the mass use of mobile communication technologies, especially smartphones. From a methodological point of view, qualitative research was used in order to grasp the meanings people give to the use of such technologies. Data were gathered through 24 focus groups and 20 in-depth interviews with youths aged between 16 and 25 years of age in Santiago de Chile between 2014 and 2015. Results show that the people's uses of mobile communication systems would be creating changes in the daily experience of time and space, and in the way in which they give stability, structure and meaning to the intersubjective world. The article concludes that the concept of ubiquitous everyday life, or hyper everyday life, may explain the meaning of the current transformations.
\end{abstract}

Key words: everyday life, time, space, mobile phone, ontological security.

Resumen: El presente trabajo analiza la relación entre la vida cotidiana y la masificación del uso de las tecnologías móviles de comunicación, especialmente de los teléfonos inteligentes. Desde el punto de vista metodológico, se utilizó un dispositivo de investigación cualitativa que buscó hacer surgir las significaciones que las personas otorgan al uso de dichas tecnologías. La información fue recolectada mediante 24 grupos focales y 20 entrevistas en profundidad a jóvenes entre 16 a 25 años en Santiago de Chile entre 2014 y 2015. Los resultados indican que los usos de los sistemas móviles de comunicación por parte de las personas, estarían produciendo cambios en la experiencia cotidiana del tiempo y del espacio, y en la forma a través de la cual los sujetos otorgan estabilidad y estructura al mundo intersubjetivo. Se concluye que el concepto de híper cotidianidad, podría explicar el sentido de las transformaciones en curso.

Palabras clave: vida cotidiana, tiempo, espacio, teléfono móvil, seguridad ontológica. 


\section{Introduction $^{1}$}

Taking the history of mass media into account, we notice that the emergence of new media is related to new social practices (Bravo, 2013). That was the case of radio and later television, mass media that had (and still have) an impact on social change on the use of free time, the concept of entertainment and its meaning, the forms adopted by the family and interpersonal relationships, on educational processes, and the expansion and dissemination of knowledge, to name a few.

This allows us to consider that the process of mass access and use of new communication technologies, we currently experience, may be the context for the profound transformation of social practices and the people's meaning of reality.

New media, new practices and meanings arise: mobile phones are cameras, alarm clocks, video game platforms, TV screens, calendars and above all, Internet browsers. Change in interpersonal interactions by using online communication applications (Kiss and Castro, 2004). Change in the families' quality of life by means of the use of technology (Guadarrama and Valero, 2009).

Traditional media organizations criminalize protest and at the same time, new social movements use social media platforms (Rovira-Sancho, 2013). Newspapers and TV networks are supplied with images from amateur eyewitnesses, now transformed into correspondents, in virtue of the possibility to share their YouTube videos (Thorson, 2013). Additionally, hundreds of thousands of commercial transactions are made on an everyday basis on the web, from mobile devices or desktop computers, changing the relationships between people, market and consumption (Cetina and Bruegger, 2002).

The new practice of using Facebook on smartphones has, in turn, changed Facebook (Goggin, 2014). New modes of learning, experiencing and organizing sexuality (Brickell, 2012). The increasing supply of content moving from one medium to another, portability and interactivity are all phenomena that are changing media production practices, circulation and consumption, its contents and discourses, as well as the human subjects'

1 This article presents the results of the research project Fondecyt Regular $\mathrm{n}^{\circ} 1140935$, "Technological convergence and everyday life: cultural transformations in contemporary Chile" (2014-2016), funded by Fondo Nacional de Ciencia y Tecnología (FONDECYT) of Chile. 
practices and the users' relationship with various technological systems and devices which have been called "new media" (Jenkins, 2006).

This article is based on the results of a qualitative research on young Chileans about their uses and significances of communication systems and technologies between 2014 and 2015. It analyzes some of the transformations that appear to be occurring in everyday life from the adoption, uses and significances that human beings make of new technologies, especially mobile communication technologies.

Our research results suggest the emergence of profound changes in the temporal-space dimension of the human subjects' everyday experience and in the way by means of which they provide the intersubjective world with stability, structure and meaning. From a phenomenological point of view, these changes are displayed both in a compression of the vivid present (Schutz, 1945) and in the adoption of new strategies for the construction of ontological security (Giddens, 1991).

The article argues that such transformations seem to produce an enhanced everyday life, a hyper everyday life, in as much as mobile technologies give temporal-space constancy and continuity to interpersonal relationships, beyond what is possible from the physical co-presence of human subjects in any given moment or place, and because such mobile technologies allow "trusting from a distance" (Silverstone, 1994), something characteristic of institutional technological systems of communication.

In sections 2 and 3, we describe our theoretical perspective on both the concept of everyday life and technological experience. In section 4, we present the research methodology. In section 5, the results and analysis are exposed. Finally in section 6 , we present the conclusions of this research.

\section{Everyday life, communication technologies and ontological security}

According to Kalekin-Fishman (2013: 714), everyday life "is relatively new as an explicit concern to sociologists". In this regard, it is difficult to establish any trends or major theories, however Kalekin-Fishman argues that the concept can be observed from sociological traditions, such as the German, British, French and American. They have a common stress on small groups and some key mechanisms for shaping everyday life: language, rules, positions and performance. What is interesting is her claim that "everyday life is a realm where social scientists find it practical to combine several perspectives [and that] the elaboration of tools that fully meet the demands of in-depth research into everyday life may indeed be seen as opening the way to new 
paths to transdisciplinarity" (Kalekin-Fishman, 2013: 724). Back (2015) also highlights that everyday life studies allow us to develop an eye for detail and attentiveness to the seemingly unimportant.

In social science, it is possible to identify two main perspectives on daily life according to the emphasis on the action of reproduction or social transformation. On the one hand, those that characterize it as a process of individual reproduction that makes social reproduction possible, in which the moral order consists of daily activities governed by rules that are taken for granted (Goffman, 1956; Garfinkel, 1967; Heller, 1984, among others). On the other hand, those that emphasize practices by means of which people appropriate the organized and pre-conceptualized social space to transform it from specific and limited actions in daily life (Lefebvre, 1962; De Certeau, 1984; Ibáñez, 1994, among others).

Albeit, what came up from the development of our research was, indeed, the evidence of tension between the regulatory domain of social structure (norms, adaptations and moral values) and the transformative action of people (meaning, appropriations and ruptures) related to the uses of mobile communication technologies. For this reason, we deemed useful to use the perspective developed by Giddens on daily life.

In his structuration theory, Giddens (Giddens, 1984) adds a new dimension to the problem of the theoretical conception of everyday life in social theory by placing the relevance of people as agents who create reality in the center of the recurrent sociological debate on structure/action relationship, giving these agents a fundamental role for their subjective experiences and the way in which they give meaning to their actions as producers of the social world.

Giddens underscores the agents' transformative abilities, because he thinks that structures are born, mainly, as elements that come from everyday knowledge and from people's practical wisdom. This knowledge is neither theoretical nor abstract, but practical and empirical on how to use rules and resources in various situations and contexts of everyday life, Giddens calls it practical consciousness, as opposed to collective consciousness, as it refers to the set of shared moral and ethical beliefs which work as a structure's conservative force.

According to Giddens (1991), what sustains this production of the social world by the agents is ontological security:

The notion of ontological security ties in closely to the tacit character of practical consciousness -or, in phenomenological terms, to the "bracketings" presumed by the "natural attitude" in everyday life. [...] What makes a given response "appropriate" or "acceptable" necessitates a shared -but unproven and unprovable- framework of 
reality. A sense of the shared reality of people and things is simultaneously sturdy and fragile. Its robustness is conveyed by the high level of reliability of the contexts of dayto-day social interaction, as these are produced and reproduced by lay agents (Giddens, 1991: 36).

This reliability allows people to give their identity continuity through a reflexive process that demands physical corporeal presence, communication and one-another relationships; such process is crucial for the constitution of society. This reliability is built since childhood and continues later by means of social life's routine practices:

The concept of routinization, as grounded in practical consciousness, is vital to the theory of structuration. Routine is integral both to the continuity of the personality of the agent, as he or she moves along the paths of daily activities, and to the institutions of society, which are such only through their continued reproduction (Giddens, 1984: 60).

Habits, rituals and routines that support everyday life, maintain and give continuity to the world we experience, making it familiar and predictable. From Giddens' (1991: 16) standpoint, in modern societies with "the emergence of more extensive forms of social systems" (social and technological changes, population increase and city growing, and the need of large-scale social coordination, among others) the largest part of significant social relations that give us reliability about the world or reality, are mediated by abstract signals, different from face-to-face encounters and the physical corporeal presence, as in pre-modern societies. In other words, ontological security in modern society has been built in relation to the spatial and temporal separateness of human subjects. This way, people have learned to "trust from a distance" (Silverstone, 1994: 7) by relying on information they receive about what is real, even though many times this information is unproven and unprovable for them.

With the purpose of examining the arguments about the television's role in current society, Silverstone adopts Giddens's approach to everyday life, focusing on the notion of "ontological security". According to Silverstone, mass media, especially television, is an agent of ontological security: "What is the issue here? It is the place of television in the visible and hidden ordering of everyday life; in its spatial and temporal significance; in its embeddedness in quotidian patterns and habits, as a contributor to our security" (Silverstone, 1994: 19).

Silverstone highlights the role of television in everyday life programming and its routinization in modern societies that works in conjunction with family, labor organization, entertainment and free time, building together a predictable and trustworthy environment for people. 
Not only does television give us information or entertainment, but also goes alongside the construction of everyday routines through the mediatization (Couldry, 2008) of social interest in big events, as well as keeping company while we make household chores. Television programming organizes and is organized by the people's everyday-life pace to the point of merging with the routine structure that gives sense and continuity to people and their environment (Amigo et al., 2014: 139).

Radio as well as cinema and newspapers are integrated into people's routines and, in turn, create new practices in dynamics quite similar to the one pointed out by Silverstone about television. Taking them as a whole, these mass media, usually called "traditional", as opposed to the concept of "new media" (Jenkins, 2006) or "social media" (Mandiberg, 2012), can be considered institutional technological systems of communication, in as much as they are: a) external to the sphere of human subjects' interpersonal relationships; $b$ ) they establish a type of communication and interaction which is vertical and regulated -"one-to-many communication"- (Scolari, 2010: $78)$; c) they require a complex and specialized technological infrastructure for their operation; $d$ ) they correspond to social structures, materially and symbolically organized, whose purpose transcends the individuals; and, $e$ ) they operate in a systematic, structured and recurrent way over the entire society or a sizeable part of it.

As mentioned earlier, in spite of playing a role in the construction of routines that give human subjects reliability on the world, these institutional technological systems of communication operate in a very different way from interpersonal relationships and face-to-face encounters in the construction of ontological security. These institutional technological systems of communication act by allowing us to "trust from a distance", cooperate to make reliable, structure and predict the complex and chaotic world which they refer to, help us control uncertainty.

Sanz and Stancik (2014) upgraded the previous argument to understand our present time. Analyzing the practices of online information search in Google, they say:

We appropriate the concept of ontological security to explore the autonomy of the cultural dimension of online search, which has gone largely unanalyzed in the literature [...]. Through a series of qualitative and quantitative empirical exercises, we show that search engines construct ontological meaning as much as they provide utility, relate to unconscious individuation even more strongly than rational instrumentality and help in dealing with existential questions about the informational chaos of reality generated during the realization of global events. Even in the seemingly individualistic 
information society, search brings a clearer sense of the position of the subject in relation to the collectivity (Sanz and Stancik (2014: 252).

Therefore, there would be, at least, two complementary instances from which people construct their ontological security in current society. The first instance, a basic and fundamental way, face-to-face interpersonal relationships in the flow of everyday life; the other instance, institutional technological systems of communication that link current routines and create new ones. Between these two poles, which role can devices and technological systems, usually called "new media", play?

\section{Technological experience as articulation of time and space}

According to Kenzie Burchell (2015: 36):

In the contemporary urban environment, the conditions for communication are in abundance, having shifted and extended to include multiple overlapping possibilities for interaction through mobile devices, personal computers, and online platforms such that traditional domains of activity have been subsumed within a relational domain of communication activity. This involves not only an extension of interaction across spaces of activity but also the remapping of how interpersonal communication practices are woven into the temporality and embodied practices of everyday life.

Therefore, the incorporation of mobile communication technologies to people's daily life seems to have effects on their conceptions and practices related to time and space.

The temporal-space dimension is key to understand the articulation of everyday life in so far as routine practices are the ones that establish the relationship between time and space in people's daily experience. This argument leads us mainly to notice the temporal-space dimension in people's relationship with their technologies in everyday life. For this reason, we became interested in Schutz phenomenological sociology, since this perspective understands intersubjective relationships, the core of the world of everyday experience, as temporal-space relationships.

Schutz and Luckmann (1973: 3) argue that in the life-world take place everyday life experience and the construction of meaning that human subjects make of the world and that the world makes on them take place: "Only in the world of everyday life can a common, communicative, surrounding world be constituted. The world of everyday life is consequently man's fundamental and paramount reality".

According to Schutz (1945), what makes it possible to experience an everyday life shared by all people is the vivid present. This phenomenological 
dimension is not about an objective time or space measurable in seconds or centimeters, but rather in the way of experimenting and giving spatial and temporal meaning to intersubjective relationships:

He and I, we share, while the process lasts, a common vivid present, our vivid present, which enables him and me to say: "We experienced this occurrence together". By the We-relation, thus established, we both — he, addressing himself to me, and I, listening to him - are living in our mutual vivid present, directed toward the thought to be realized in and by the communicating process. We grow older together (Schutz, 1945: 543).

From this perspective, the present is not a line dividing past and future but a temporal-space flow that gives constancy to the agents' action, their communication and interactions. In this sense, the vivid present is also an existential and cognitive referential point that defines the relationship between the agent with the predecessors (Vorwelt) of the past social world, with their contemporaries (Nebenmenschen) and fellow men (Mitmenschen) of the present and with their successors (Folgewelt) of the future social world (Schutz, 1972).

Schutz argues that the subjective world is not private but common to all and shared by all, in a common time and space. This makes it possible to think that the introduction of new objects in the world of human subjects' experiences can generate new structures of relevance, different from the previous ones, nevertheless common to those who experience them. This is to say, changes experienced by people incorporating new devices and technological systems into their routines are not limited to the sphere of their individual experience, but correspond to the transformation of intersubjectivity that gives new sense to the practices and meanings of their everyday life.

This way, from a phenomenological point of view, human subjects' technological experience can be understood as the integration of technology into the domain of the agents' vivid present. Integration not only of devices and technological systems used on a daily basis, but also of discourses, meanings and representations of technology. This way, people share a vivid present about their technological experience that allows them to build intersubjectivity that gives a particular sense to such devices and systems.

\section{Methodology}

One way to understand the sociocultural practices of the people's uses and appropriation of mobile communication technologies is by means of the analysis of their discourses, as these reflect the senses, values and meanings that people construct about such practices. 
In order to grasp the people's social discourse on their technological experience, we used two ways to gather information: focus groups and indepth interviews.

Focus group is a technique to gather the declarative opinion of a group. Participants feel motivated by the experience of others to express their own perspectives: "when someone talks or act, he does it in the word of the group. That is the common sense" (Canales, 2013: 184). In-depth interview is a technique that searches for the attributed values and meanings of an individual, at least in a conversation, on a particular subject. Contrary to focus groups, the absence of people, other than the interviewer, allows the interviewees to display their subjectivity and their own perception of common sense on the subject matter which they are asked about.

According to Jane Ritchie, "in-depth interviews have key features: they combine structure with flexibility, are interactive (the material is generated by the interaction), get 'below the surface' (which is the meaning of indepth), generative (new knowledge is likely to be created) and highlight the importance of language (interviewers express themselves through it)" (Ritchie et al., 2014: 183).

Because of its qualitative character, our research selected a theoretical, non-probabilistic structural sample (Marshall, 1996), by means of which the phenomena of uses, appropriation and meaning we studied could be expressed. Within this framework, we established three structural elements for sampling: 1) Main users; considering international information, and in particular for Chile (Halpern, 2012), the main users of mobile communication technologies are young people aged between 16 and 25 years, we focused our sampling on such age group. 2) Access and penetration level; demographic information (INE, 2012) shows that the Chilean population is approximately 17 million people and most of them belong to middle and lower classes; in this context, data is revealing: in March 2015 there were about 23.708.036 mobile phone accounts, with an approximate average of 1,4 mobile phone numbers per person (SUBTEL-IPSOS, 2016). According to the same data, $3 \mathrm{G}$ and $4 \mathrm{G}$ mobile Internet accounts reached an amount of 14.138 .493 in March 2015. This is to say, the distribution of mobile communication technology in Chile crosses the social structure. Sampling was carried out in middle-high, middle and lower social classes with the purpose of including the majority of Chilean society and the one with the most consumer access to technology. 3) Gender; for the same statistical reason (the distribution of mobile communication technology in Chile), both genders are represented, this way, we made the same number of focus groups and interviews to men and women. 
Such situation allows us to establish, at least in theoretical terms, that the structural phenomena of the meaningful process of the users of mobile communication technologies are: social class, age and gender, as well as other characteristics such as occupation (or unemployment), geographical zone of the house, which may be relevant for a localized study, but for our study they depended on the others.

Both focus groups and in-depth interviews were used as homogenous sampling criteria considering: a) both sexes separated: half men, half women (control of gender variable); b) age groups: people aged between 16 and 25 years (divided into two groups: 16-18 and 19-25 years of age); c) socioeconomic group, divided into upper-middle class and lower-middle class, each separated (control of socio-economic variable); and $d$ ) location: people living in Santiago, Chile.

We had 24 focus groups and held 20 in-depth interviews between April and July 2014, and March and May 2015. In each focus group, eight people, who did not acquaint one another, participated (random selection according to homogenous sampling criteria). Both the focus groups and in-depth interviews were recorded and transcribed in their entirety. The information was processed using NVivo 10.

Given the semantic fields from the research objectives, the questions to trigger conversations in the focus groups and interviews were the following: what is the first thing that comes to your mind when you hear "technology"? How do you picture future technologies? According to you, which one is used more? What are they used for: entertainment, work, study, interpersonal relationships and information? In what places: home, work, transport, school, university? How could a day without technology be? How has life been transformed by technology?

We used discourse analysis to access the attributed values and significance that the younger and older groups from the sample declared about their daily practices and the type of relationships they established with the new communication technologies.

The main results from the information gathered were organized into three categories: a) significance of technology; b) temporality; and, c) technology attributed values. These categories were subdivided into 24 subcategories in the following way: a) significance of technology: transformations, interpersonal relationships, entertainment, education and culture, work, study, media diet, remediation, uncertainty, audio-visual culture, publicity, Internet, fiction; b) temporality: past, present, generational change, time acceleration, future, obsolescence; and, c) technology attributed values: positive, negative, neutral, dual and contradictory. 


\section{Results and analysis: the space and time of technological experience}

The temporal-space dimension is key to understand everyday life articulation. For this, the phenomenological concept of technological experience, understood as the generation of new inter-subjective highpoints through the uses and appropriations of technology, allowed us to understand the meanings constructed by people around mobile communication technologies.

In the analysis that follows we independently consider the temporal and spatial dimension of the technological experience. This operation is only analytical, as it allows us to dissemble a phenomenon that is a simultaneous and unified whole in the human beings' technological experience.

\section{Time and technological experience}

One first key element in the research, found in people's discourse, is the sense of temporality they build around their technological experience.

When people refer to their personal, practical, concrete and actual experience of technological systems and devices, what Giddens calls human subjects' practical consciousness, the attributed value of those is clearly positive. They are signified as elements that facilitate problem solving and daily routines, and also an effective and efficient interface for interpersonal relationships and identity markers that highlight personality traits that are important and meaningful for each one in relation with the others.

I use WhatsApp to talk to my parents: it's easy, more practical, and cheaper. In fact it's free (woman, 22, middle-lower class).

People that design technology think that less is better. They put things that are more practical to use in mobile phones, something that works with the touch of a finger. The idea is to innovate, do you see? (man, 19, middle-lower class).

In Facebook, I generally like to share my work a lot, my photographs, university assignments, my drawings. I'm trying to make an artist profile on Facebook, but it's not working (man, 20, middle-upper class).

Nevertheless, alongside those predominant positively attributed values and meanings, we also find speeches that refer to "negative externalities" regarding the use of technologies, such as information overload, loss of privacy, the end of face-to-face interactions, among others.

For example yesterday, I was thinking of deleting WhatsApp because I really think I spend too much of my time on it. I want to study and suddenly, unconsciously, I check it knowing there's nothing (man, 21, middle-upper class). 
It's like a vice. I try not to open Facebook (in fact, I disabled my phone alerts), but in the end I have to follow it. It's desperate. Most of what is published is garbage, but one feels compelled to read it and, if I don't answer my friends, they get angry (woman, 17, middle-upper class).

When people's conversation and interactions about their technological experience become abstract (detached from daily routines), discourses and values are frequently negative. In this regard, the emergence of technology signified as "negative" in people's speech is to link to a situation in which human subjects abandon their practical consciousness of the technological experience. This apparent paradox is highly indicative of the presence, in the modes of the signification used by the interviewees, of a dimension of consciousness more representative of an "ought-to-be" moral, trans-individual, theoretical and abstract.

This awareness that relates, in this case, technological change and risk, diseases and dehumanization, is frequent in human dialogue when they distance themselves from their technological experience. This mode of manifestation of the present in people's speeches, is similar to what Durkheim, Giddens and others have called collective consciousness.

I think people are becoming more individualistic every time, they don't share with others. They spend their days talking on the phone. If they're in a restaurant, instead of talking to the person in front, they are chatting on WhatsApp [...] Technology is destroying people socially, because you can stay at home, lie in bed, talk to 20 thousand people, why bother going out for an ice-cream, coffee and a chat? (woman, 23, middle-upper class).

I think technology draws people near when they are far away, but it separates those who are close, because at the table, usually, while sitting the father, mother and children all have mobile phones and pay attention to other things (man, 17, middle-upper class).

About the past, it is frequent to see how technology is signified as a biographical and historical marker. Human subjects also construct their generational identity through their relationship with technological devices and systems. They feel themselves part of the same community of experience, as opposed to the old or new ones. In Schutz's terms, they become theirfellow men. The element that binds them and establishes their borders is some technological "breakthrough" produced in some moment in history or in the people's biography. There is a point from which they feel comfortable and identify with a particular "technological state", which is shared with other subjects.

I think we are the ones living in times of technological breakthroughs, we witnessed the change to flat TVs and to today's LCDs. We lived in 
times without Facebook nor Twitter. To us it shouldn't be that important compared to today's children: they were born with all that technology, we just acquired it (man, 25, middle-lower class).

From the practical consciousness of technological experience, the technological past is represented as precarious, naive or obsolete. While speeches remain concrete, technological past is signified as the pre-historic phase of the currently accomplished progress.

I couldn't live like in the past: no Internet, no mobile phones, with fax machines or coin phones. I think everything was more difficult, from heating food to, I don't know, homework. My father told me when he was a kid his house was the only one in the neighborhood with a telephone, a land line, so if someone wanted to reach a neighbor my father was called (man, 20, middle-upper).

Think about it, people wrote letters before. The other day my mobile phone broke and I was without the phone for many days and I wanted to die because I felt unconnected. And people wrote letters before! And the reply wasn't quick, it took months (woman, 24, middle-upper class).

On the other hand, when the interviewees assumed the perspective of collective consciousness, they constructed meaning that went back to themes which cherished the past and the village, despising the present and the city; mainly, they referred to the loss of face-to-face relationships and the exhausting pace of current society versus the past signified as bucolic, more human, warm and calm.

People talked more to each other before, they had time to go out, for walks and visiting friends. None was a Facebook's slave or reliant on WhatsApp. Everything was calmer, less stressful, not like today, everyone goes faster and faster (man, 21, middle-lower class).

Before you could do homework in a group, go to the house of school friends. Now it's only through the Internet. Communication has been lost by young people (man, 25, middle-lower).

The results about the construction of meaning of future technology is quite different. While the past is interpreted through known actions, experienced or objectified by the media or historical discourses, the future is uncertain, a place for the projection of an abstract collective consciousness.

I would like to know if there's a point in which technology will affect us in such a way that we end up with a chronic disease such as AIDS. I think with so much technology we will create new diseases (man, 18, middle-lower class).

I don't know, I think in the future people are going to be totally dependent on technology, they will be dominated by machines, I don't know, as slaves, not realizing what's going on (woman, 17, middle-upper). 
One of the frequent sources in people's speeches regarding the construction of an idea of the future related to technology is the one that arises from images, discourses and representations of the future, contained and spread by the cultural industry, mainly, fiction films.

People will be fat as in Wall-E, sitting all day, doing nothing and with machines giving them everything they need (man, 18, middle-lower class).

I imagine the future as in Terminator, with people fighting against robots (man, 20, middle-upper class).

I don't know, I think the future will be like The Matrix, everyone dominated by machines and not knowing what is really going on (woman, 17, middle-upper).

In the people's imagined technological future, many fears are assigned to social, environmental and individual catastrophes. A world dominated by machines, human holocaust, the loss of individuals to the mass society, among others.

However, between future uncertainty and the security that brings people's technological experience, there is a space for risk within the people's discourses, a future that overlaps with the present, source of uncertainty here and now, colliding symbolically with the vivid present of the technological experience. While the technological future is uncertain, the "immediate future" is a permanent threat, an actual risk, something to fight against. The new consumer practices and the use of technology that arise are signified as dangerous, especially when children use them.

Compare my brother, he was born with a PlayStation and a computer. He prefers to talk on Skype with their friends instead of going out with them. In fact, children of much younger age have technology. The problem is that they can unknowingly browse the Internet and find something, but you never know the content they can find (woman, 24, middle-lower class).

Now children of 12,13 or 14 years, just learning what life is, have access to things we never had and because they are children it could be very bad for them (man, 17, middle-upper class).

A friend told his brother: 'let's play football' and the child sat on the couch to play PlayStation (man, 22, middle-upper class).

As stated before, an important source of security is what is known, the familiar, the routine. The speed of technological changes overwhelms some people in the sense that it creates new landscapes they scantly know or know nothing about. Contexts for a vivid present are impossible to generate, but not the new ones that share, in parallel, their world. 
Everyday life regularity is faced with the emergence of social and technological changes that occur increasingly faster. This situation seems to have an effect on the inter-subjectivity of the vivid present, making it more ephemeral every time.

This is to say, rapid change seems to increase the level or feeling of people's uncertainty. Not only what is known is a refuge, but also the measure to value and give meaning to what is positive or negative, correct or incorrect, valid or despicable. Ontological security is built upon the stable, the routine and the predictable. The speed of change operates in the opposite way.

\section{Space and technological experience}

As we previously stated, the notion of vivid present neither exclusively refers to a temporal nor a chronological dimension. It refers to a "wide here" and "an extended now" in inter-subjectivity. According to Schutz, it is the present of the action of agents and, therefore, it also corresponds to the space where this action occurs.

Alongside the forms and meanings that assume the construction of the temporality of technological experience, a second element relevant to our research was the spatial meaning related to it. There are three significant phenomena related to space in human beings' technological experience: the shortening of intersubjective distances; the fusion or transposition of the fields of action; spatial continuity and constancy.

In the first case, the shortening of space and intersubjective distances can be verified mainly from the creation of virtual communities as a source and sustain of daily routines. People can make a presence regularly in the common space; they can seek shelter and be recognized, be available and value the availability of others to maintain communication and interactivity on social networks on the Internet.

I have Facebook open all day long. I'm connected all the time with my friends. With WhatsApp I'm connected to my parents because it's easier for them. If they send me a message and I'm busy, I can answer them later and there's no problem... basically, I'm connected to them all day (woman, 21, middle-upper class).

Technology takes people closer. Today through a mobile phone you can talk to someone from China. It doesn't matter where he is, near or far, what's important is having an Internet connection (man, 25, middle-lower class).

In the same way as we noticed technological temporality in the previous section, when people talk from their practical consciousness, the attributed 
value of the shortening or decreasing the intersubjective distance is signified as positive, comfortable, assured. When they assume the perspective of an abstract collective consciousness, the critical moral discourse arises.

There're a lot of people all day on social networks, chatting, posting, they can't stop. They don't know what reading a book or a walk in the park is like. They're sick (man, 19, middle-lower class).

However, when returning to their concrete technological experiences, this overwhelmed vision changes radically. Their contacts on Facebook, WhatsApp, Twitter or other social media, represent a heritage, a possibility, relational capital. Actually, the most precious is the constancy of relationships with a relatively small number of contacts, generally, friends and close family. The core of relationships that can assure them and are trustworthy.

I never talk to my family but when I go to Facebook I just know everything that's going on with them. Twitter too (man, 22, middle-lower class).

You can have thousands of friends on Facebook but in the end I talk to my close friends. To the others, I post them once in a while, just to keep communication. In this way, one can know everything that goes on (woman, 19, middle-upper class).

In relation to human beings' technological experience related to space, the phenomenon of fusion or transposition of the people's fields of action is produced. Workplaces, free time, entertainment or interpersonal relationships overlap and operate simultaneously.

I can be working but I'm always on Facebook or searching news on the Internet. Before it was just work, but now one can combine things. Being more connected allows me to know all the time about my friends and family without stop working (man, 25, middle-lower class).

It doesn't matter if I'm in a class, on the metro or at home; I'm always connected with friends all day. My best friend went to live in Canada and we're still connected as before. Whether I'm at university or at home, every day I see her on Facebook (woman, 24, middle-upper class).

The frontiers between the public and the private in the space of the vivid present become blurred. Like a small village, where the public and the private tend to overlap, in social networks this distinction is also weak.

I publish superficial things, such as parties, meetings with friends, travels. But there are many people on Facebook posting feelings, their problems, ending relationships, being sad. People post almost anything (man, 21, middle-upper class).

However, the phenomenon that is most significant for us in human beings' technological experience about space, and of great relevance in understanding the ongoing social change, is the continuity and constancy 
of space, either of interpersonal relationships or institutional technological systems of communication that allow mobile communication technologies, mainly represented by the use of smartphones.

It happens to me at work. Today my boss WhatsApped me at 6 in the afternoon, not even an email, a WhatsApp!: 'You haven't sent me the presentation' and I said: 'OK, I will' so that he wouldn't bother me any more, later or tomorrow saying it's urgent (man, 24, middle-lower class).

Before the mobile phone, I had to do everything from the office. If I had to send an urgent email, I had to be next to the computer. Today I go out for lunch or shopping and I get an email I answer it immediately, without always having to be in the office (woman, 25, middle-lower class).

Mobile communication technologies provide continuity to the sphere of interpersonal relationships that give people security, introducing new routines, uses and significances. Everyday life is being colonized by new practices, systems and technological devices of communication.

If a professor tells you something in class, you can look it up immediately on the phone. If this is not correct, then you don't see him as an authority. It happened to me when I had my daughter, I had postnatal depression and my mother was trying to help me by telling me how to do things. What I did first was to look it up on the Internet to see if what she said was right (woman, 24, middle-lower class).

The situation of being permanently online can be overwhelming and disturbing for many people. However, in spite of the fatigue that is generated by the permanent administration of so much communication and information, people usually prefer to be on social media given the retribution (affective and cognitive) that brings them the continuity and constancy of interpersonal relationships.

Several times I have closed Facebook because it is tiring to answer and watching what others have been publishing, especially when it's mainly nonsense, but I have always regretted it. I prefer to know what goes on. A person without Facebook or Twitter is nobody (man, 25, middle-upper class).

I was bored watching others -I said- I must have my own life. It doesn't matter what others do and I closed it. The first week my friends told me 'it will only last one week'. Truth is, the first time I closed it I lasted one day, then one week. The last time I really resisted and my hands were hurting to open it and to know what others were doing, but finally I opened it because a friend asked me to tag her. One really doesn't exist if one is not there. It's like the only connection. To talk to friends one can use WhatsApp but sometimes you need to see the photographs on Facebook or the events (woman, 22, middle-lower class). 
Mobile communication technologies have allowed the introduction of an element of rupture within the previous forms of construction of ontological security. Now, the big empty spaces of life in the city, long journeys in public transport, work and long study hours are filled or complemented by social networks and their messages, sounds and familiar images. We can carry, transport with us and give constancy to the space of interpersonal relationships, but also to the fields of action of the game, music, work, entertainment and information.

When I'm on the metro going to university, I'm listening to some music and, sometimes, I play online. Other times, I go to YouTube to watch a video. I also chat by WhatsApp: I ask classmates for some assignment or if there's something to read (man, 16, middle-upper class).

If time acceleration in the technological experience produces uncertainty, the constancy and continuity of space have the opposite effect that counter balances it. From the place of practical consciousness, mobile communication technologies become a sanctuary, an armor against the speed of change they themselves make possible.

\section{Conclusion: technological experience as hyper everyday life}

According to the scientific debate of the past decade on the social consequences of widespread access to new technologies (Jensen, 2010), there were three convergent technological elements closely related to the transformation in the modes of experimenting and signifying daily life by the people: the development and widespread use of interactive web 2.0, the development of social media on the Internet and the widespread use of screens. On the one hand, web 2.0 has become an articulating element of media and convergent technology, such as television, computer, smartphones or game consoles, generating a continuity between their specific uses but also allowing the circulation of content, representations and discourses between them (Jensen, 2010), all of this in the framework of development and popularization of interactive communication (Hine, 2004).

On the other hand, this articulation is supported on audio-visual devices that have taken the common form of interactive "screens" (Dwyer, 2010), allowing users to access in a continuous and independent way, from the specific technological device, contents, representations and discourses that circulate on the web (Murduchowicz, 2008). Lastly, the widespread use of social media on Internet (Facebook, Twitter, Instagram, etc.) has created a 
social and interactional space without precedents, generating the expansion of global forms of interpersonal and group communication, almost without space-time limitations (Bettetini, 2008). These three phenomena represent an important rupture with the people's rituals and practices in traditional media (Jensen, 2010).

However, from our fieldwork analysis it was possible to identify a second recent and significant rupture. It is the widespread availability of mobile communication technologies, especially smartphones, a phenomenon that seems to be changing even more profoundly people's daily life. Mobile communication technologies, in the context of Internet centrality, give a different sense to the continuity of uses and contents that allow the other concurring technologies, in the sense that they place people in a situation to be "online" 24 hours a day, anywhere with a $3 \mathrm{G}, 4 \mathrm{G}$, Wi-Fi or Bluetooth connection. From a phenomenological point of view, what makes the difference between the uses of smartphones and the uses of other convergent media technologies is their full incorporation into the most diverse aspects of people's daily life (Chan, 2015).

Seiler and Kidwell (2016) have studied the relationship between mobile phones and the structure of lifeworld. Their findings show that nowadays people develop a sense of "telecopresence" with other subjects who are significant for them. In other words, some important people (close family members) are dislocated (they are not physically here with me), but permanently "present" thanks to mobile phones.

Mobile communication technologies seem to return us to the neighborhood, to the village, shortening time and distance that separate us from our friends and close family, strengthening those routines that are a source of reliability in the constancy and continuity of the world. Nevertheless, this is not a return to a pre-modern village, neither to its temporality nor its space. Mobile communication technologies allow the constancy and continuity of interpersonal relationships beyond of what is possible with the physical co-presence of people in a concrete space and time. It allows and pre-supposes permanent availability regardless of the place, moment or time of the day.

Moreover, such technologies by virtue of the fact that they contain institutional communication systems such as television, radio, databases, dictionaries, newspapers, magazines or cinema (to name a few), increase the possibility of constructing ontological security from a distance, a feature of modernity according to Giddens. 
Television and other technologies and institutional communication systems have given us the possibility to become world spectators, giving structure and stability to our environment beyond the limits of our close community, by incorporating external experience into our everyday life experience at home and neighborhood (Silverstone, 1994). Nowadays, this at-a-distance construction of ontological security (Giddens, 1984) merges with constant and permanent interpersonal relationships.

In human beings' technological experience, this articulated characteristic of mobile communication technologies allow an enhanced everyday life, a hyper everyday life, which co-exists in a single device that we carry almost 24 hours 7 days a week, an extensive field of interpersonal relationships, constant and continuous, as well as a space of permanent availability and access to institutional technological systems of communication.

The concept hyper everyday life summarizes the uncertainty produced by the speed and dizziness of technological and social changes, and the protection that brings the continuity of the elements which allow the construction and re-construction of ontological security. Hyper everyday life is a result of the compression of an intersubjective time and space enabled by mobile communication technology.

\section{References}

Amigo, Bernardo et al. (2014), "Telenovela, recepción y debate social", in Cuadernos. Info, no. 35, Chile: Universidad Católica de Chile.

Back, Les (2015), "Why everyday life matters: class, community and making life livable", in Sociology, vol. 49, no. 5, United Kingdom: Sage.

Bettetini, Gianfranco (2008), "L’Audiovisivo", in Scolari, Carlos, Hipermediaciones. Elementos para una teoría de la comunicación digital interactiva, Spain: Gedisa.

Bravo, Cecilia (2013), "Histoire de la télévision au Chili", in Amigo-Latorre, Bernardo and Lochard, Guy [comps.], Identités télévisuelles. Une comparaison France-Chili, France: l'Harmattan.

Brickell, Chris (2012), "Sexuality, power and the sociology of the Internet", in Current Sociology, vol. 60, no. 1, United Kingdom: Sage.

Burchell, Kenzie (2015), "Tasking the everyday: Where mobile and online communication take time", in Mobile Media \& Communication, vol. 3, no. 1, United Kingdom: Sage.

Canales, Manuel (2013), Escucha de la escucha, Chile: LOM Ediciones.

Cetina, Karin and Bruegger, Urs (2002), "Inhabiting technology: the global lifeform of financial markets", in Current Sociology, vol. 50, no. 3, United Kingdom: Sage.

Chan, Michael (2015), "Mobile phones and the good life: Examining the relationships among mobile use, social capital and subjective well-being", in New Media \& Society, vol. 17, no. 1, United Kingdom: Sage. 
Bernardo Amigo, Francisco Osorio y María Cecilia Bravo. Mobile communication technologies and ontological security

Couldry, Nick (2008), "Mediatization or mediation? Alternative understandings of the emergent space of digital storytelling", in New Media \& Society, vol. 10, no. 3, United Kingdom: Sage.

De Certeau, Michelle (1984), The practice of everyday life, USA: University of California Press.

Dwyer, Tim (2010), Media convergence, England: McGraw-Hill.

Garfinkel, Harold (1967), Studies in ethnomethodology, USA: Prentice-Hall.

Giddens, Anthony (1984), The constitution of society: outline of the theory of structuration, England: Polity Press.

Giddens, Anthony (1991), Modernity and self-identity. Self and society in the late modern age, USA: Stanford University Press.

Goffman, Ervin (1956), The representation of self in everyday life, England: University of Edinburgh.

Goggin, Gerard (2014), "Facebook’s mobile career”, in New Media \& Society, vol. 16, no. 7, United Kingdom: Sage.

Guadarrama, Luis and Valero, Jannet (2009), “Tecnologías de la información y la comunicación [TIC] desde el concepto de 'calidad de vida", in Convergencia, vol. 16. Available at: www.redalyc.org/articulo.oa? id=10512244009 [March 25 ${ }^{\text {th }}, 2016$ ].

Halpern, Daniel (2012), Nuevas tendencias y diferencias culturales en el uso de telefonía móvil. Available at: http://www.iab.cl/wp-content/files_mf/tendencias_telefonia_movil. pdf [March 25 $\left.5^{\text {th }}, 2016\right]$.

Heller, Agnes (1984), Everyday life, England: Routledge and Kegan Paul.

Hine, Christine (2004), Etnografía virtual, Barcelona: UOC.

Ibáñez, Jesús (1994), Por una sociología de la vida cotidiana, Spain: Siglo XXI.

INE (Instituto Nacional de Estadísticas de Chile) (2012), Sintesis de resultados del Censo 2012, Chile: Publicaciones INE.

Jenkins, Henry (2006), Convergence culture: where old and new media collide, USA: New York University Press.

Jensen, Klauss (2010), Media convergence: The three degrees of network, mass, and interpersonal communication, USA: Taylor \& Francis.

Kalekin-Fishman, Devorah (2013), "Sociology of everyday life”, in Current Sociology, vol. 61, United Kingdom: Sage.

Kiss, Diana and Castro, Eduardo (2004), "Comunicación Interpersonal en Internet", in Convergencia, no. 36. Available at: http://convergencia.uaemex.mx/article/ view/1534/1172 [March 25 $\left.{ }^{\text {th }}, 2016\right]$.

Lefebvre, Henri (1962), Critique de la vie quotidienne (II): Fondements d'une sociologie de la quotidienneté, France: L’Arche.

Mandiberg, Michael (2012), The social media reader, USA: New York University Press.

Marshall, Martin (1996), "Sampling for qualitative research", in Family Practice, vol. 13, no. 6, United Kingdom: Oxford University Press.

Murduchowicz, Roxana (2008), Los jóvenes y las pantallas, Spain: Gedisa.

Ritchie, Jane et al. (2014), Qualitative research practice: a guide for social science students and researchers, England: Sage.

Rovira-Sancho, Guiomar (2013), "Activismo mediático y criminalización de la protesta: medios y movimientos sociales en México", in Convergencia, no. 61. Available at: http://convergencia.uaemex.mx/article/view/1049/778 [March 25 $\left.{ }^{\text {th }}, 2016\right]$. 
Sanz, Esteve and Stancik, Juraj (2014), "Your search -'ontological security'- matched 111,000 documents: an empirical substantiation of the cultural dimension of online search", in New Media \& Society, vol. 16, no. 2, United Kingdom: Sage.

Schutz, Alfred (1945), "On multiple realities", Philosophy and Phenomenological Research, vol. 5, no. 4. Available at: http://www.jstor.org/stable/2102818 [March 25 $\left.{ }^{\text {th }}, 2016\right]$.

Schutz, Alfred (1972), The phenomenology of the social world, Evanston, USA: Northwestern University Press.

Schutz, Alfred and Luckmann, Thomas (1973), The structures of the life-world, vol. 1, USA: Northwestern University Press.

Scolari, Carlos (2010), Hipermediaciones. Elementos para una teoria de la comunicación digital interactiva, Spain: Gedisa.

Seiler, Steven and Kidwell, Josiah (2016), "Defining the mobile-digital situation within perpetual telecopresence: An exploratory study of the impact of mobile phones on the life-world", in Sociological Spectrum, vol. 36, no. 4, United Kingdom: Taylor \& Francis.

Silverstone, Roger (1994), Television and everyday life, New York: Routledge

SUBTEL-IPSOS (2016), VII Encuesta de Acceso, Usos y Usuarios de Internet, Chile: Subsecretaría de Telecomunicaciones del Gobierno de Chile.

Thorson, Kjerstin et al. (2013), "Youtube, Twitter and the Occupy Movement: Connecting content and circulation practices", in Information Communication \& Society, vol. 16, no. 3, United Kingdom: Taylor \& Francis.

Bernardo Amigo. Doctor in social sciences, Université Catholique de Louvain, Belgium. Titular professor of the Department of Sociology of the University of Chile. Researcher and coordinator of the Laboratorio Cultura Mediática (www.culturamediatica.cl). Associated researcher in Laboratoire Communication et Politique of CNRS, France (www.lcp. cnrs.fr). Main research lines: sociology of communication and the media, socio-anthropology technology and political communication. Recent publications: Amigo, B., Bravo, M. C., Sécail, C.; Lefébure, P. and Borrell, A., "Television, diversity and cultural hegemony: A comparative study of the dominant ethnic stereotypes in the television systems of Chile and France", in Cuadernos.info (39), Chile: Universidad Católica de Chile (2016); Amigo, B.; Bravo, M. and Osorio, F., "Telenovela, reception and social debate”, in Cuadernos.Info (35), Chile: Universidad Católica de Chile (2014); Amigo Latorre, B. and Lochard, G., Identités télévisuelles. Une comparaison FranceChili, France: l'Harmattan (2013).

Francisco Osorio. Doctor in Philosophy and Social Anthropologist from the University of Chile. Associated Professor of the Department of Anthropology of the University of Chile. Director of Journal Cinta de Moebio (www.moebio.uchile.cl). Researcher of the Laboratorio Cultura 
Mediática (www.culturamediatica.cl). Main research lines: epistemology and anthropology of the media. Recent publications: López, P., Osorio, F., Gallegos, V. and Cáceres, M. D., "Liderazgo escolar y eficacia colectiva en escuelas públicas de Bogotá”, in Magis, Revista Internacional de Investigación en Educación 9(18), Bogotá: Universidad Javeriana (2016); Osorio, F. and Delamaza, Gonzalo, "Enhancing democracy. Public policies and citizen participation in Chile", in Social Anthropology, 23(3), United Kingdom: Wiley (2015); Osorio, F., "Arguments connecting social sciences and philosophy", in Forum Qualitative Sozialforschung, 15(2), Berlin: Free University of Berlin (2014).

María Cecilia Bravo. Doctor in Social Sciences, Université Catholique de Louvain, Belgium. Assistant Professor of the Institute of Communication and Image of the University of Chile, where she is the Director of PreGraduate School. Researcher in the Laboratorio Cultura Mediática (www. culturamediatica.cl). Associated researcher of Laboratoire Communication et Politique of CNRS, France (www.lcp.cnrs.fr). Main research lines: history of the media, research methodology in communication and political communication. Recent publications: Amigo, B., Bravo, M. C., Sécail, C., Lefébure, P. and Borrell, A., "Television, diversity and cultural hegemony: A comparative study of the dominant ethnic stereotypes in the television systems of Chile and France", in Cuadernos.info, (39), Chile: Universidad Católica de Chile (2016); Amigo, B., Bravo, M. and Osorio, F., "Telenovela, reception and social debate", in Cuadernos.Info, 35, Chile: Universidad Católica de Chile (2014); Lagos, P., Peña, P. and Bravo, M. C., in Vilches, L., “Transmedialidad en Chile: ¿el fin del modelo actual de televisión?”, in Convergencia y transmedialidad, Spain: Gedisa (2012).

Reception: July $16^{\text {th }}, 2015$

Approval: October $6^{\text {th }}, 2016$ 
